\title{
DIVERSIFIKASI EKSPOR NON MIGAS INDONESIA KE PASAR NON TRADISIONAL
}

\section{Diversification of Indonesia's Non-Oil Gas Export to Non-Traditional Markets}

\author{
Hotsawadi ${ }^{1}$, Widyastutik ${ }^{2}$ \\ ${ }^{1}$ Program Studi IImu Ekonomi, Sekolah Pascasarjana, Institut Pertanian Bogor \\ 2Departemen Ilmu Ekonomi, Fakultas Ekonomi dan Manajemen, Institut Pertanian Bogor \\ Jl. Kamper, Kampus IPB Darmaga, Bogor, 16680, Jawa Barat, Indonesia \\ Email: hotsawadi@gmail.com
}

Naskah diterima: 15/04/2020; Naskah direvisi: 29/09/2020; Disetujui diterbitkan: 16/11/2020;

Dipublikasikan online: 1]/12/2020

\begin{abstract}
Abstrak
Penelitian ini bertujuan untuk menganalisis diversifikasi ekspor non migas Indonesia ke pasar non tradisional. Metode penelitian yang digunakan adalah analisis statistik deskriptif dengan pendekatan pengelompokan (clustering), Structural Match Index dan $\square$ emand Index, serta regresi data panel. Hasil penelitian menunjukkan bahwa negara yang diidentifikasikan sebagai negara non tradisional potensial adalah Brazil, Pantai Gading, Mesir, Georgia, Jamaica, Kazakhstan, Kuwait, Myanmar, Nigeria, Norway, Oman, Pakistan, Russian Federation, Trinidad and Tobago, Turkey, United Arab Emirates, dan Uruguay. Hasil regresi data panel menunjukkan bahwa Random Effect Model merupakan model yang terbaik untuk menjelaskan faktor-faktor yang memengaruhi ekspor non migas Indonesia ke negara non tradisional. Hasil regresi menunjukkan bahwa GDP riil negara tujuan, populasi negara tujuan, nilai tukar riil, FDI dan kualitas pelabuhan Indonesia berpengaruh signifikan secara statistik terhadap ekspor non migas Indonesia ke negara non tradisional potensial tersebut. Beberapa rekomendasi kebijakan yang perlu dilakukan untuk meningkatkan ekspor non migas ke negara tujuan non tradisional diantaranya perlu dilakukan intelejen pasar mengenai kebutuhan dan selera dari masing-masing negara non tradisional atas produk Indonesia, peningkatan kualitas pelabuhan Indonesia dan kebijakan tambahan yang memberikan insentif untuk menarik Foreign Direct Investment ke Indonesia.
\end{abstract}

Kata Kunci: Diversifikasi Ekspor, Demand Index, Non traditional, Random Effect Model, Structural Match Index

\begin{abstract}
This study aims to analyze the diversification of Indonesia's non-oil and gas exports to nontraditional markets. The research method used is descriptive statistical analysis with a clustering approach, Structural Match Index and demand index, and panel data regression. The results showed that countries identified as potential non-traditional countries were Brazil, Ivory Coast, Egypt, Georgia, Jamaica, Kazakhstan, Kuwait, Myanmar, Nigeria, Norway, Oman, Pakistan, Russian Federation, Trinidad and Tobago, Turkey, United Arab Emirates, and Uruguay. The panel data regression results show that the random effect model is the best model to explain the factors that influence Indonesia's non-oil exports to non-traditional countries. The results show that the real GDP of the destination country, the population of the destination country, the real exchange rate, FDI and the quality of Indonesia's ports have a statistically significant effect on Indonesia's non-oil exports to these potential non-traditional countries. Then, in this study there are several policy recommendations that need to be done to increase non-oil and gas exports to non-traditional destination countries including market intelligence regarding the needs and tastes of each non-traditional country for Indonesian products, improving the quality of Indonesian ports and additional policies that provide incentives to attract Foreign Direct Investment to Indonesia.
\end{abstract}


Keywords: Export Diversification, Demand Index, Non-traditional, Random Effect Model, Structural Match Index

JEL Classifications: F13, F15, F18

PENDAHULUAN

Sektor non migas merupakan sektor potensial bagi perdagangan Indonesia. Hal ini disebabkan hingga saat ini struktur ekspor Indonesia masih didominasi sektor non migas. Data Kemendag (2019) menunjukkan bahwa 88\% komponen ekspor Indonesia ditopang oleh sektor non migas. selain itu, data dari WITS (2019) juga menunjukkan bahwa dari tahun 2016 hingga 2018 kontribusi nilai ekspor non migas terhadap total ekspor Indonesia menunjukkan kondisi yang cenderung stagnan pada nilai share rata-rata sebesar $90 \%$ terhadap total ekspor.

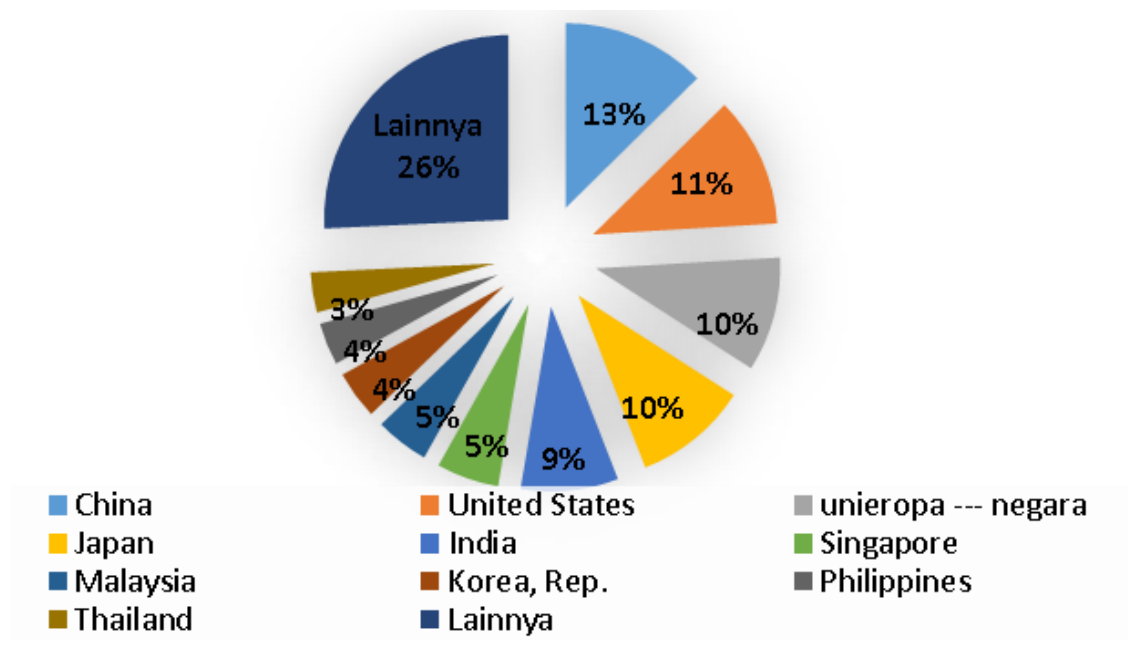

\section{Gambar 1. Persentase Share Ekspor Non Migas Indonesia ke 10 Besar Negara Sasaran Ekspor dan Lainnya, 2014-2018}

Sumber: WITS (2019), diolah

Salah satu faktor yang memengaruhi nilai ekspor Indonesia adalah permintaan impor dari negara mitra dagang. Menurut Salvatore (1997), Asramantika \& Oktaviani (2009) perdagangan internasional akan terjadi ketika adanya disparitas harga antar kedua negara, serta kelebihan penawaran di negara tersebut akan menjadi komponen ekspor sedangkan kelebihan permintaan di negara lain akan menjadi komponen impor. Oleh sebab itu, kondisi ini mengindikasikan bahwa besaran nilai ekspor dari negara eksportir akan sama dengan besaran nilai impor dari negara importir. 
Gambar 1. menunjukkan bahwa negara yang termasuk ke dalam 10 besar sebagai sasaran ekspor non migas Indonesia dari tahun 2014 hingga 2018 adalah China, India, Philipina, Amerika Serikat, Singapura, Thailand, Uni Eropa, Malaysia, Jepang, dan Korea Selatan. Posisi pertama dan kedua sebagai sasaran ekspor non migas Indonesia adalah China dan Amerika Serikat dengan persentase share ekspor masing-masing sebesar 13\% dan 11\%. Kemudian posisi ketiga sebagai sasaran ekspor non migas Indonesia ialah Uni Eropa dan Jepang dengan share masing masing sebesar 10\%. Namun total persentase share ekspor non migas Indonesia ke 10 negara tersebut selama periode 2014 hingga 2018 hanya sebesar 74\% dari total seluruh ekspor non migas Indonesia ke dunia. Hal ini menunjukkan bahwa sasaran pasar ekspor non migas Indonesia masih terfokus atau dominan ke negaranegara tertentu. Kondisi tersebut mengindikasikan bahwa adanya ketergantungan pasar ekspor non migas Indonesia terhadap negaranegara tersebut.

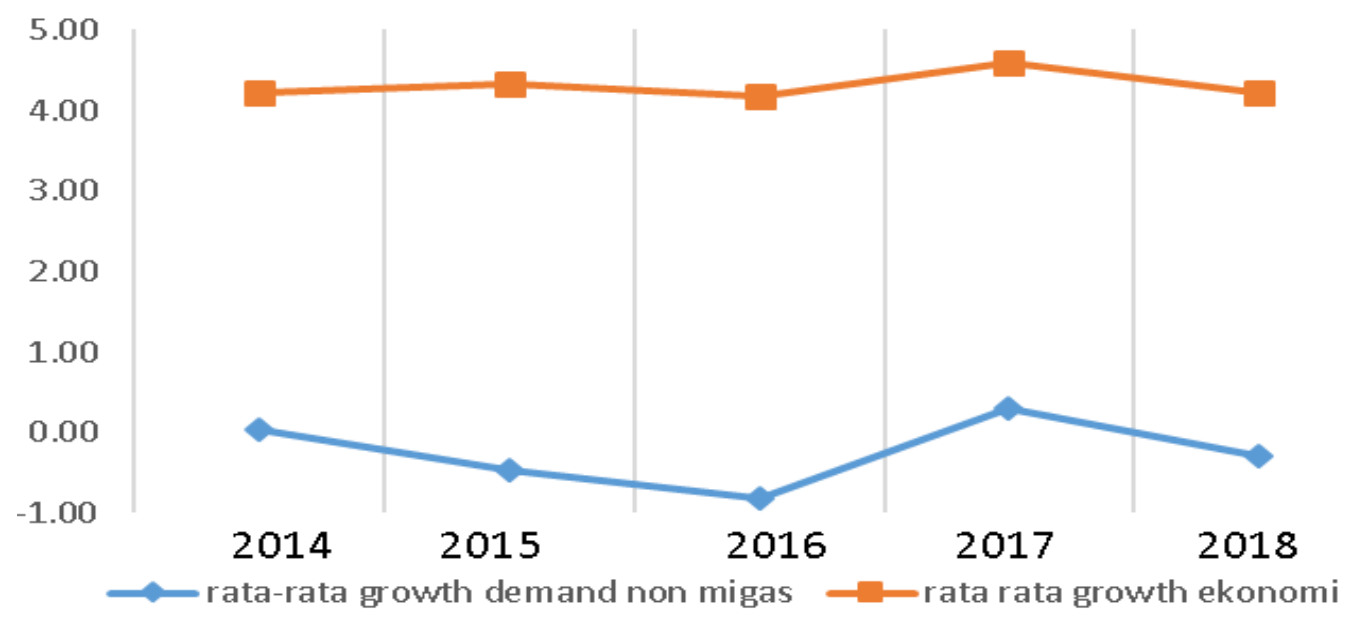

Gambar 2. Rata-rata Growth Ekonomi dan Demand Impor Non Migas 10 Besar Negara Sasaran Ekspor Indonesia, 2014-2018 (\%)

Sumber: WITS (2019) dan WDI (2019), diolah

Sisi permintaan negara growth ekonomi dan demand impor importir ditentukan oleh kondisi negara yang termasuk 10 besar pertumbuhan ekonomi, produk pesaing, sasaran ekspor non migas Indonesia serta kebijakan terkait di negara bersifat fluktuatif. Gambar 2. importir (Lubis, 2010). Kondisi rata-rata menunjukkan bahwa kondisi rata-rata 
pertumbuhan demand impor negara mitra dagang lebih rendah dari pada rata-rata pertumbuhan ekonominya. Kondisi ini menunjukkan bahwa terdapat kecenderungan negara tujuan ekspor tersebut mengalami perlambatan terhadap permintaan impor meskipun secara ukuran pertumbuhan ekonomi tetap mengalami kenaikan. Hal ini akan berdampak pada menurunnya kinerja perdagangan sektor non migas Indonesia. Sebab secara teoritis nilai ekspor suatu barang dan komoditas dari negara eksportir dipengaruhi oleh demand impor (permintaan impor) dari negara importir (Arifin \& Mawardi, 2017).

Perlambatan demand impor negara tujuan yang cenderung menurun menunjukkan indikasi adanya permasalahan, baik eksternal maupun internal. Beberapa permasalahan eksternal dan internal yang dihadapi negara mitra dagang diantaranya adalah masalah perang dagang (Trade War), geopolitik, bahkan persoalan yang menuju terhadap strategi menghambat perdagangan internasional. Sebagai contoh, perang dagang yang terjadi antara China dan Amerika Serikat memberikan dampak secara langsung (direct impact) dan tidak langsung (indirect impact) terhadap perekonomian dunia dan negara lainnya seperti pengalihan perdagangan, pengalihan investasi dan keterkaitan kebelakang (Damayanti et al, 2018).

Permasalahan eksternal dan internal yang terjadi di negara mitra dagang berpengaruh negatif terhadap kinerja perdagangan Indonesia. Ketidakpastian finansial, guncangan perekonomian dunia, atau masalah eksternal maupun internal di negaranegara mitra dagang akan memengaruhi kinerja neraca perdagangan (Oktaviani \& Novianti, 2008). Sebagai contoh, melemahnya lokomotif utama yang memengaruhi ekonomi global seperti China, Amerika Serikat, dan Uni Eropa menyebabkan penurunan pada kinerja ekspor Indonesia. Selain itu, krisis global yang terjadi juga cenderung menurunkan ekspor, output dunia, serta menekan ke bawah tingkat inflasi dan suku bunga (Sugema, 2012). Oleh sebab itu, untuk mendorong dan meningkatkan kinerja perdagangan, Indonesia harus melakukan dan menetapkan strategi baru dalam perdagangan. Strategi diversifikasi pasar merupakan pilihan strategi yang mendasar terlebih bagi negara-negara berkembang termasuk Indonesia. selain itu, diversifikasi pasar 
ekspor juga merupakan salah satu terobosan yang diekspektasikan meminimalisir dampak krisis global yang memengaruhi perekonomian negara mitra dagang (Oktaviani, Novianti \& Widyastutik, 2016). Kemudian, menurut Haryotejo (2013) diversifikasi sasaran atau negara tujuan ekspor merupakan salah satu cara atau alternatif yang dapat dilakukan agar kinerja ekspor Indonesia tetap sustainable.

Diversifikasi pasar merupakan strategi menambah sebaran pasar sebagai salah satu strategi jangka panjang dalam meningkatkan ekspor Indonesia (Hadiyanto, 2015). Beberapa penelitian terdahulu telah meneliti diversifikasi pasar ekspor Indonesia dengan melakukan klasterisasi pasar non tradisional diantaranya penelitian yang dilakukan oleh Sabarudin (2013) dan ITAPS FEM IPB dan Bank Indonesia (2019). Menurut Sabarudin (2013), negara non tradisional merupakan negara dan entitas ekonomi yang tidak konsisten masuk dalam 15 besar tujuan ekspor Indonesia selama 40 tahun atau lebih. Pada penelitian ini akan mengadopsi definisi negara non tradisional oleh penelitian ITAPS FEM IPB dan Bank Indonesia (2019), dimana negara non tradisional merupakan definisi bagi negara-negara yang tidak konsisten masuk dalam 15 besar sasaran ekspor Indonesia selama 30 hingga 40 tahun.

Berdasarkan uraian di atas, maka penelitian ini akan menganalisis tentang diversifikasi ekspor non migas Indonesia ke pasar non tradisional. Adapun rumusan masalah dalam penelitian ini sebagai berikut.

1. Negara-negara mana yang termasuk pasar non tradisional?

2. Bagaimana posisi ekspor non migas Indonesia di negara-negara non tradisional?

3. Apa saja faktor-faktor yang memengaruhi ekspor non migas Indonesia ke negara-negara non tradisional?

\section{METODE}

Penelitian ini menggunakan metode analisis kuantitatif tren ranking dengan pendekatan klasterisasi atau pengelompokan untuk memperoleh definisi dan negara-negara yang tergolong sebagai pasar non tradisional. Kemudian, metode analisis Demand Index dan Structural (Exports) Match Index (SMI) digunakan untuk menganalisis posisi ekspor non migas Indonesia di pasar non tradisional, serta metode analisis regresi data 
panel yang digunakan untuk menganalisis faktor penentu ekspor non migas Indonesia. Terdapat tiga alternatif model data panel yaitu Common Effect Model (CEM) atau Pooled Least Square (PLS), Fixed Effect Model (FEM), dan Random Effect Model (REM) (Firdaus M, 2018). pada pendekatan ini model yang terbaik digunakan untuk menganalisis faktor penentu ekspor non migas Indonesia adalah random effect model. Hasil ini didasarkan dari uji penentuan model data panel diantara uji Chow, Uji Hausman, dan Uji LM. Adapun tahapan-tahapan yang dilakukan dalam studi ini sebagai berikut:

1. Menggolongkan negara yang termasuk ke dalam klasifikasi tradisional dan non tradisional dengan merujuk kepada metode klasterisasi atau pengelompokan studi dari Sabarudin (2013) dan ITAPS FEM IPB dan Bank Indonesia (BI) (2019).

2. Setelah memperoleh definisi dan negara-negara yang termasuk klasifikasi pasar non tradisional, dilanjutkan ke tahap analisis posisi ekspor non migas Indonesia di pasar tersebut dengan menggunakan pendekatan metode analisis Structural (Exports) Match Index
(SMI) dan demand index. Kedua hasil metode tersebut akan dicross atau ditarik garis melintang dimana sumbu $X$ merupakan nilai perhitungan SMI (identifikasi kecocokan antara ekspor-impor) sedangkan nilai $\mathrm{Y}$ merupakan hasil perhitungan demand index (identifikasi potensi permintaan). Metode analisis ini merujuk pada studi Stankovsky dan Wolfmayr (2004).

3. Negara atau pasar yang diidentifikasi sebagai potensial sasaran ekspor non migas Indonesia dari analisis sebelumnya yaitu demand index dan SMI, kemudian dilanjutkan ke tahap analisis faktorfaktor yang memengaruhi ekspor non migas Indonesia ke pasar tersebut menggunakan metode analisis data panel.

Proses pengelolahan data pada penelitian ini menggunakan aplikasi atau software Microsoft Excel 2010 dan Stata SE 11.

\section{Metode Kuantitatif}

Dalam penelitian ini metode analisis kuantitatif yang dilakukan adalah metode kuantitatif analisis statistik tren ranking dengan pendekatan clustering melalui program bantuan Microsoft Excel 2010. Metode 
ini bertujuan untuk memperoleh atau mendapatkan definisi dari negara non tradisional serta klasifikasi negara yang termasuk pada pasar tersebut. Model analisis yang digunakan ini mengacu pada penelitian yang ditulis oleh Sabaruddin (2013), Bank Indonesia dan ITAPS FEM IPB (2019). Metode kuantitatif analisis deskriptif yang dilakukan terdiri dari beberapa tahapan sebagai berikut.

1. Pengolahan data perdagangan non migas antara Indonesia dengan negara mitra dagang berdasarkan penggunaan data World Integrated Trade Solution (WITS) klasifikasi SITC Revision 1 yang terdiri dari 250 negara dari tahun 1967 hingga 2018.

2. Kemudian dilanjutkan dengan memfilterisasi negara-negara yang termasuk kedalam anggota World Trade Organizatioan (WTO) dan anggota Uni Eropa sehingga dari 250 negara menjadi 125 negara dan 1 region.

3. Selanjutnya, dipilih negara yang selama 30 sampai 40 tahun berturut-turut selalu masuk 15 besar sebagai sasaran ekspor non migas Indonesia atau diidentifikasi sebagai negara tradisional. Serta negara diluar kategori tersebut atau tidak konsisten masuk 15 besar sebagai sasaran ekspor non migas Indonesia diidentifikasikan ke dalam klasifikasi negara non tradisional.

\section{Demand Index}

Pendekatan demand index digunakan untuk melihat potensi pasar atau permintaan impor negara non tradisional terhadap ekspor Indonesia. Metode analisis demand index yang digunakan merujuk terdahap metode analisis demand index yang dikembangkan oleh Stankovsky \& Wolfmayr (2004). Pada analisis demand index yang merujuk kepada model yang dikembangkan oleh Stankovsky \& Wolfmayr (2004) terdapat tujuh indikator yang digunakan untuk menganalisis potensi permintaan impor negara non tradisional diantaranya GDP riil 2018, rata-rata pertumbuhan GDP riil 2014-2018, GDP per kapita riil negara partner 2018, ratarata pertumbuhan GDP per kapita riil negara partner 2014-2018, impor negara partner 2018, rata-rata pertumbuhan impor negara partner 2014-2018, dan populasi negara partner. Akan tetapi, untuk memperoleh satuan yang sama ketujuh indikator tersebut distandarisasi terlebih dahulu dengan menggunakan metode standar deviasi yang terdapat pada software 
Microsoft excel. Berdasarkan hal tersebut, secara garis besar adapun rumus dari pendekatan analisis demand index sebagai berikut (Stankovsky \& Wolfmayr (2004)).

$$
\mathbf{D} \mathbf{I}_{\mathbf{i j}}=\sqrt{\sum_{j=1}^{n}\left(K_{j \mathrm{i}}-K_{j k}\right)^{2}}
$$

Adapun keterangan dari pendekatan model tersebut sebagai berikut.

$D_{i j}=$ Demand Index Indonesia kepada negara Partner

$K_{j i}=$ Indikator Makro Negara Partner

$K_{j k}=$ Indikator Makro Negara Benchmark

$J=$ Indikator Makroekonomi Perhitungan analisis demand index memasukkan indikator makro negara Benchmark di dalam persamaan. Negara Benchmark merupakan negara yang indikator makronya menjadi base atau patokan di dalam perhitungan demand index. Berdasarkan studi dari Stankovsky \& Wolfmayr (2004), penentuan indikator makro negara Benchmark didasari dari nilai minimum setiap variabel makroekonomi yang digunakan pada metode analisis tersebut. Apabila nilai demand index semakin tinggi dari nilai rata-rata demand index seluruh negara yang diteliti, maka posisi permintaan impor negara tujuan juga semakin tinggi, begitupun sebaliknya.

\section{Structural (Exports) Match Index (SMI)}

Structural (Exports) Match Index (SMI) merupakan metode yang digunakan untuk menunjukkan hubungan antara jarak vektor impor suatu negara $\left(m_{\mathrm{ij}}\right)$ dengan vektor ekspor suatu negara $\left(X_{i j}\right)$ dalam perdagangan. Metode analisis Structural (Exports) Match Index (SMI) merupakan indeks yang dikembangkan oleh Stankovsky dan Wolfmayr (2004). Pendekatan SMI akan menunjukkan sebenarnya struktur matched atau kecocokan perdagangan antara dua negara. Perhitungan atau metode SMI akan menunjukkan kondisi atau pasar ekspor yang berpotensi terhadap perdagangan antar negara. Rumus persamaan dari Structural (Exports) Match Index (SMI) sebagai berikut (Stankovsky dan Wolfmayr, 2004).

$$
C_{j k}=\arccos \frac{\sum_{j=1}^{n} x_{j i} m_{j k}}{\sqrt{\sum_{j=1}^{n} x_{j i}^{2}} \sqrt{\sum_{j=1}^{n} m_{j k}^{2}}}
$$

Adapun keterangan dari pendekatan model tersebut sebagai berikut.

J : Komoditas

i : Indonesia 
n : Total komoditas

x : Ekspor

$\mathrm{m}$ : Impor

k : Negara Mitra

Pada persamaan dan metode ini, Structural (Exports) Match Index ini akan menjadi justifikasi bagi identifikasi mitra dagang (ekspor) non tradisional yang potensial bagi Indonesia. Apabila nilai Struktural Match Index semakin rendah dari nilai rata-rata dari seluruh nilai SMI negara yang diteliti, maka kondisi tersebut menunjukkan tingkat kecocokan yang tinggi antara ekspor non migas Indonesia terhadap impor non migas negara non tradisional.

\section{Analisis Regresi Data Panel}

Dalam menganalisis faktor-faktor yang memengaruhi ekspor non migas Indonesia ke negara non tradisional yang diidentifikasikan sebagai potensial sasaran ekspor menggunakan pendekatan analisis regresi panel data. Model estimasi yang digunakan merujuk terhadap model analisis yang dilakukan oleh Mardiah (2019), Namun untuk memperoleh model analisis yang terbaik dilakukan modifikasi atau penyesuaian terhadap variabel-variabel dari model tersebut. Variabel-variabel yang diestimasi diantaranya GDP riil negara mitra, populasi negara mitra, nilai tukar riil (Rp/LCU), jarak ekonomi antara Indonesia dengan negara mitra dagang, kualitas pelabuhan Indonesia, serta Foreign Direct Investment (FDI) Indonesia. Adapun spesifikasi model yang akan digunakan pada penelitian ini dimodelkan sebagai berikut:

Ln $\mathbf{N E N M}_{i k t}=\alpha+\beta_{1} \operatorname{Ln}\left(\mathrm{GDP}_{\mathrm{kt}}\right)+\beta_{2}$ $\operatorname{Ln}\left(\mathrm{EX}_{\mathrm{ikt}}\right)+\beta_{3} \ln \left(\mathrm{Pop}_{\mathrm{kt}}\right)+\beta_{4} \ln \left(\mathrm{ED}_{\mathrm{ikt}}\right)+\beta_{5}$ $\ln \left(\mathrm{QPI}_{\mathrm{it}}\right)+\beta_{6} \ln \left(\mathrm{FDI}_{\mathrm{it}}\right)+\varepsilon_{\mathrm{ikt}}$

Adapun keterangan model tersebut sebagai berikut.

Ln NENMikt : Total nilai ekspor non migas Indonesia ke negara non tradisional potensial sasaran ekspor pada tahun 2014-2018 (USD)

Ln $G D P_{k t}$ : GDP riil negara non tradisional potensial sasaran ekspor pada tahun 2014-2018 (USD)

Ln $E X_{i k t} \quad$ : Nilai tukar riil mata uang Indonesia terhadap negara non tradisional potensial sasaran ekspor pada tahun 2014-2018 (Rp/LCU)

Ln Popkt : Populasi negara non tradisional potensial sasaran ekspor pada tahun 2014-2018 (Jiwa) 


\begin{tabular}{|c|c|}
\hline Ln $E D_{i k t}$ & $\begin{array}{l}\text { Jarak ekonomi antar } \\
\text { Indonesia dengan negara } \\
\text { non tradisional potensial } \\
\text { sasaran ekspor pada } \\
\text { tahun 2014-2018 }(\mathrm{km})\end{array}$ \\
\hline Ln $Q P l_{i t}$ & $\begin{array}{l}\text { Kualitas pelabuhan } \\
\text { Indonesia pada tahun } \\
\text { 2014-2018 (indeks) }\end{array}$ \\
\hline $\operatorname{Ln} F D l_{i t}$ & $\begin{array}{l}\text { Foreign Direct Investment } \\
\text { (FDI) Indonesia pada } \\
\text { tahun 2014-2018 (USD) }\end{array}$ \\
\hline I & : Indonesia \\
\hline $\mathrm{k}$ & $\begin{array}{c}\text { Negara non tradisional } \\
\text { potensial sasaran ekspor }\end{array}$ \\
\hline $\mathrm{t}$ & $\begin{array}{l}\text { : periode waktu Penelitian } \\
\text { 2014-2018 }\end{array}$ \\
\hline$\varepsilon_{i k t}$ & : error term \\
\hline$\alpha$ & : intercept \\
\hline$\beta_{n}$ & : slope $(n=1,2, \ldots)$ \\
\hline
\end{tabular}

Data

Data yang digunakan dalam penelitian ini adalah pendekatan data sekunder. Data sekunder yang digunakan dalam penelitan ini adalah data ekspor non migas Indonesia dan Impor non migas negara non tradisional dengan pendekatan SITC Revision 1, GDP riil, GDP perkapita riil, populasi, jarak ekonomi, nilai tukar riil, kualitas pelabuhan dan FDI Indonesia dari tahun 2014-2018. Data sekunder diperoleh dari instansi pemerintah atau lembaga-lembaga terkait lainnya seperti Badan Pusat Statistik (BPS), Kementerian Perdagangan Republik Indonesia (Kemendar RI), World Integrated Trade Solution (WITS), World Development Indicator (WDI), UNCTAD, dan jurnal-jurnal penelitian serta literatur-literatur yang terkait.

\section{HASIL DAN PEMBAHASAN}

\section{Definisi Negara Tradisional dan Non}

\section{Tradisional}

Dalam penelitian ini, definisi negara tradisional dan non tradisional merujuk kepada hasil penelitian yang dilakukan oleh ITAPS FEM IPB dan Bank Indonesia (2019). Negara tradisional merupakan negara yang konsisten masuk 15 besar secara berturut-turut selama 30 hingga 40 tahun sebagai sasaran ekspor Indonesia. Hasil penelitian ini menunjukkan bahwa negara yang didefinisikan sebagai negara tradisional dalam penelitian ini terdiri dari 14 negara meliputi (1) Australia, (2) Hong Kong, (3) India, (4) Jepang, (5) Korea Selatan, (6) Philipina, (7) Singapura, (8) Thailand, (9) Uni Eropa, (10) Amerika Serikat, (11) United Kingdom, (12) Malaysia, (13) Arab Saudi, dan (14) China. Kemudian, negara-negara yang Tidak konsisten 15 besar sebagai sasaran ekspor Indonesia dalam kurun waktu 30 hingga 40 tahun merupakan 
definisi dari negara non tradisional. Republic, Niger, Congo, Rep., Cote Pada penelitian ini terdapat 111 negara d'Ivoire, Guinea, Guyana, Nicaragua, yang didefinisikan sebagai negara non Paraguay, Cuba, Gabon, Brazil, tradisional diantaranya Canada, Kuwait, Suriname, Turkey, Kenya, Myanmar, New Zealand, Norway, Argentina, Mali, Benin, Togo, Albania, Mexico, Pakistan, Switzerland, Egypt, Malawi, Zimbabwe, Burkina Faso, Arab Rep., Jordan, Yugoslavia, Chad, Israel, Russian Federation, Barbados, Brunei, Antigua and Barbuda, Ecuador, dan lain-lain (Tabel 1).

Sierra Leone, Bahrain, Central African

\section{Tabel 1. Negara-negara Non Tradisional}

\begin{tabular}{|c|c|c|c|}
\hline \multicolumn{4}{|c|}{ Negara-negara Non Tradisional } \\
\hline Canada & Morocco & Mozambique & Ecuador \\
\hline Myanmar & Sri Lanka & Vietnam & Sierra Leone \\
\hline New Zealand & Venezuela & Cambodia & Bahrain \\
\hline Norway & Panama & Guatemala & $\begin{array}{l}\text { Central African } \\
\text { Republic }\end{array}$ \\
\hline Mexico & Oman & Liberia & Qatar \\
\hline Pakistan & Bangladesh & Zambia & United Arab Emirates \\
\hline Switzerland & Nigeria & Mauritania & Honduras \\
\hline Egypt, Arab Rep. & Tanzania & Uruguay & Niger \\
\hline Jordan & Yemen & Bolivia & Congo, Rep. \\
\hline Brazil & Chile & Cameroon & Cote d'Ivoire \\
\hline Kuwait & Afghanistan & Ghana & Guinea \\
\hline Suriname & Tunisia & Trinidad and Tobago & Guyana \\
\hline Turkey & Colombia & Uganda & Nicaragua \\
\hline Kenya & Senegal & Angola & Paraguay \\
\hline Argentina & South Africa & Moldova & Cuba \\
\hline Mali & Lao PDR & Mongolia & Gabon \\
\hline Benin & $\begin{array}{l}\text { Papua New } \\
\text { Guinea }\end{array}$ & Nepal & Barbados \\
\hline Togo & Peru & Rwanda & Belize \\
\hline Albania & Madagascar & Samoa & Burundi \\
\hline Malawi & Dominica & Seychelles & Costa Rica \\
\hline Zimbabwe & $\begin{array}{l}\text { Dominican } \\
\text { Republic }\end{array}$ & Tonga & Djibouti \\
\hline Burkina Faso & El Salvador & Ukraine & Kazakhstan \\
\hline Israel & Fiji & Vanuatu & Kyrgyz Republic \\
\hline Russian Federation & Gambia, The & Solomon Islands & Maldives \\
\hline Yugoslavia & Georgia & Tajikistan & Mauritius \\
\hline Chad & Grenada & Botswana & Armenia \\
\hline Brunei & Haiti & Lesotho & Jamaica \\
\hline Antigua and Barbuda & Iceland & Namibia & Montenegro \\
\hline
\end{tabular}


Ekspor Non Migas Indonesia di Negara-Negara Non Tradisional: Demand Index dan Structural Match Index

Pada penelitian ini, dari 111 negara hanya 108 negara non tradisional yang dapat dilanjutkan ke tahap analisis posisi ekspor non migas
Indonesia ke negara-negara non tradisional menggunakan pendekatan analisis demand index dan Struktural Match Index (SMI). Hal ini dikarenakan adanya kendala keterbatasan data terhadap tiga negara seperti Yugoslavia, Cuba, dan Djibouti.

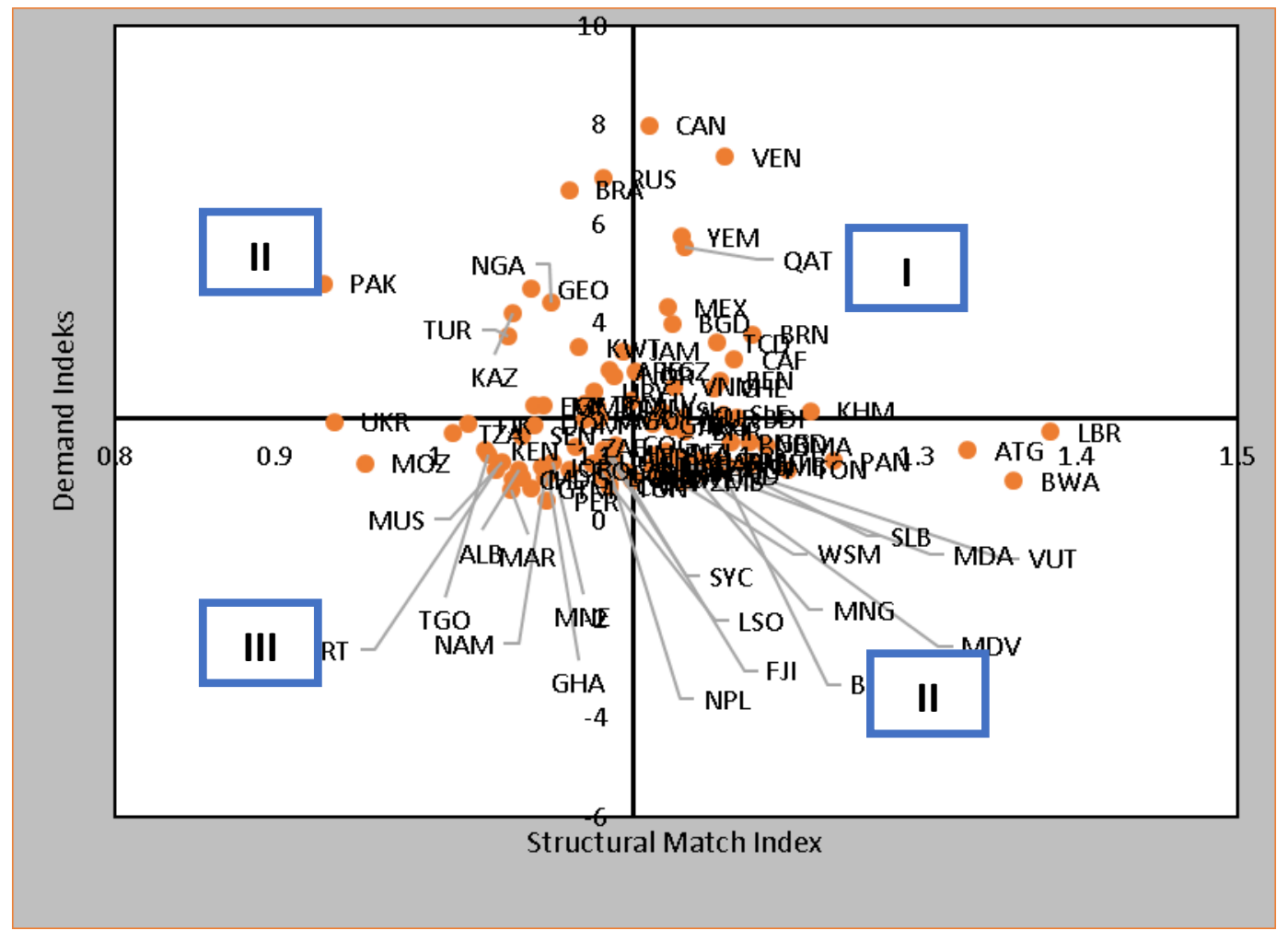

\section{Gambar 3. Demand Index dan Structural Match Index}

Sumber: WDI dan WITS (2020), diolah

Hasil analisis demand index dan SMI akan dilakukan persilangan untuk menggabungkan kedua metode analisis sehingga dapat menyimpulkan posisi ekspor non migas Indonesia ke negara non tradisional. Hasil penelitian menunjukkan bahwa terdapat empat posisi (kuadran) ekspor non migas Indonesia di negara non tradisional (Gambar 3). Kuadran I menunjukkan bahwa nilai demand index dan SMI tinggi (di atas nilai rata-rata). Hal ini menunjukkan bahwa tingginya posisi permintaan negara tersebut terhadap 
ekspor non migas Indonesia. Namun, tingkat kecocokan antara komoditas ekspor non migas Indonesia terhadap impor non migas negara tersebut dinilai kurang cocok. Kemudian, kuadran II menunjukkan nilai demand index yang tinggi (di atas nilai rata-rata) serta SMI yang rendah (di bawah nilai rata-rata). Kondisi ini menunjukkan bahwa dari posisi permintaan negara tersebut terhadap ekspor non migas Indonesia tinggi dan tingkat kecocokan antara ekspor non migas Indonesia dengan impor negara tujuan dinilai cocok. Kuadran III dan kuadran IV sama-sama menunjukkan potensi permintaan impor negara tujuan yang rendah, namun pada kuadran III nilai SMI rendah atau tingkat kecocokan tinggi, dan kuadran IV nilai SMI tinggi menunjukkan tingkat kecocokan yang rendah.

Berdasarkan Gambar 3, maka Tabel 2 menunjukkan hasil irisan antara demand index dengan Structural Match Index. Pada penelitian ini, negara yang akan dianalisis ke tahap analisis selanjutnya atau faktor-faktor yang memengaruhi ekspor non migas Indonesia ke negara non tradisional ialah negara yang diidentifikasikan sebagai potensial sasaran ekspor non migas.

Pada penelitian ini, negara yang akan dianalisis ke tahap analisis selanjutnya atau faktor-faktor yang memengaruhi ekspor non migas Indonesia ke negara non tradisionaladalah negara yang diidentifikasikan sebagai potensial sasaran ekspor non migas. Hasil studi Stankovsky \& Wolfmayr (2004) menunjukkan bahwa negara yang berpotensi sebagai sasaran ekspor suatu negara merupakan negara dengan nilai demand index tinggi dan nilai SMI rendah. Kondisi dengan nilai demand index yang tinggi mengindikasikan bahwa peluang permintaan negara tersebut tinggi sedangkan kondisi dengan nilai SMI yang rendah menunjukkan terdapat kecocokan yang tinggi antara ekspor negara eksportir dengan impor negara importir. Kuadran II merupakan negara non tradisional yang termasuk sebagai kategori negara potensial sebagai sasaran ekspor non migas Indonesia. 
Tabel 2. Negara Non Tradisional Berdasarkan Demand Index dan Structural Match Index

\begin{tabular}{|c|c|c|c|}
\hline Kuadran I & Kuadran II & Kuadran III & Kuadran IV \\
\hline & & & Antigua and \\
\hline Bangladesh & Brazil & Jordan & Barbuda \\
\hline Benin & Cote d'Ivoire & Kenya & Argentina \\
\hline Brunei & Egypt, Arab Rep. & Sri Lanka & Armenia \\
\hline Burundi & Georgia & Chile & Bahrain \\
\hline Cambodia & Jamaica & Tunisia & Barbados \\
\hline Canada & Kazakhstan & Colombia & Belize \\
\hline \multicolumn{4}{|l|}{ Central African } \\
\hline Republic & Kuwait & Senegal & Bolivia \\
\hline Chad & Myanmar & South Africa & Botswana \\
\hline Iceland & Nigeria & Peru & Burkina Faso \\
\hline Kyrgyz Republic & Norway & Madagascar & Dominica \\
\hline Lao PDR & Oman & Mozambique & El Salvador \\
\hline Mexico & $\begin{array}{l}\text { Pakistan } \\
\text { Russian }\end{array}$ & Guatemala & Gabon \\
\hline Qatar & $\begin{array}{l}\text { Federation } \\
\text { Trinidad and }\end{array}$ & Mauritania & Gambia, The \\
\hline Sierra Leone & Tobago & Cameroon & Grenada \\
\hline Suriname & $\begin{array}{l}\text { Turkey } \\
\text { United Arab }\end{array}$ & Ghana & Guinea \\
\hline Switzerland & Emirates & Uganda & Guyana \\
\hline Venezuela & Uruguay & Angola & Haiti \\
\hline Vietnam & & Ecuador & Honduras \\
\hline Vietnam & & Niger & Israel \\
\hline \multirow[t]{20}{*}{ Yemen } & & Congo, Rep. & Liberia \\
\hline & & Nicaragua & Malawi \\
\hline & & Paraguay & Maldives \\
\hline & & Mali & Moldova \\
\hline & & Togo & Mongolia \\
\hline & & Albania & New Zealand \\
\hline & & Costa Rica & Panama \\
\hline & & Dominican Republic & Papua New Guinea \\
\hline & & Fiji & Samoa \\
\hline & & Mauritius & Solomon Islands \\
\hline & & Nepal & Tonga \\
\hline & & Rwanda & Vanuatu \\
\hline & & Seychelles & Zambia \\
\hline & & Tajikistan & Zimbabwe \\
\hline & & Lesotho & \\
\hline & & Namibia & \\
\hline & & Montenegro & \\
\hline & & Morocco & \\
\hline & & Tanzania & \\
\hline & & Ukraine & \\
\hline
\end{tabular}

Sumber: WDI dan WITS (2020), diolah 
Berdasarkan Tabel 2, negara non tradisional yang diklasifikasikan sebagai negara non tradisional potensial sasaran ekspor merupakan negara yang masuk ke dalam wilayah kuadran II diantaranya Brazil, Cote d'Ivoire (Pantai Gading), Egypt Arab
Rep (Mesir), Georgia, Jamaica, Kazakhstan, Kuwait, Myanmar, Nigeria, Norway, Oman, Pakistan, Russian Federation, Trinidad and Tobago, Turkey, United Arab Emirates, dan Uruguay.

Tabel 3. Perbedaan Negara Non Tradisional yang Diidentifikasi Potensial Sasaran Ekspor oleh ITAPS FEM IPB dan BI (2019) dengan Penelitian ini

Penelitian ini

Trinidad and Tobago, Uruguay, Georgia, Jamaica, Kazakhstan, Norway, Pakistan, dan Russian Federation.
ITAPS FEM IPB dan BI (2019)

Kanada, Meksiko, Switzerland, Tanzania, Bangladesh, Qatar, Republik Congo, Guinea, Grenada, dan Iceland.

Sumber: Hasil olahan dan ITAPS FEM IPB dan BI (2019)

Hasil penelitian ini memiliki persamaan dan perbedaan dengan hasil penelitian oleh ITAPS FEM IPB dan Bank Indonesia (2019) dalam mengidentifikasi negara potensial sasaran ekspor non migas Indonesia menggunakan metode pendekatan demand index dan Structural Match Index. Persamaan negara yang diidentifikasikan oleh ITAPS FEM IPB dan Bank Indonesia (2019) dengan penelitian ini meliputi Myanmar, Brazil, Kuwait, Turkey, Oman, Nigeria, United Arab Emirates, Cote d'Ivoire, dan
Egypt, Arab Rep. Kemudian, perbedaan negara-negara yang diidentifikasi sebagai non tradisional potensial sasaran ekspor oleh ITAPS dan BI (2019) dengan penelitian ini disajikan pada Tabel 3. Perbedaan ini didasarkan dari tahun penelitian dari kedua penelitian ini. Ruang lingkup yang dianalisis oleh ITAPS dan BI (2019) menggunakan pendekatan tahun analisis data 2012 hingga 2016. Sedangkan pada penelitian ini, analisis data yang digunakan yaitu pendekatan tahun 2014 hingga 2018. 
Faktor-Faktor yang Memengaruhi Ekspor Indonesia ke Negara-Negara Non Tradisional

Estimasi model yang dapat digunakan pada data panel untuk menjelaskan faktor-faktor yang memengaruhi ekspor non migas Indonesia ke negara non tradisional dilakukan dengan menggunakan tiga pendekatan model, yaitu metode estimasi Pooled Least Square (PLS), Fixed Effect Model (FEM), dan Random Effect Model (REM). Metode Analisis model yang dapat dilakukan untuk menentukan pilihan terhadap ketiga model tersebut dengan pendekatan uji Chow, uji Hausman dan Uji Lagrange Multiplier (Tabel 4).

Tabel 4. Hasil Uji Chow, Uji Hausman, dan Uji Lagrange Multiplier

\begin{tabular}{lcl}
\hline \multicolumn{1}{c}{$\begin{array}{c}\text { Uji Model } \\
\text { Terbaik }\end{array}$} & $\begin{array}{c}\text { Nilai } \\
\text { Probabilitas }\end{array}$ & Kesimpulan \\
\hline Uji Chow & 0.000 & FEM terbaik \\
Uji Hausman & 0.323 & REM terbaik \\
Uji LM & 0.000 & REM terbaik \\
\hline
\end{tabular}

Sumber: Hasil Olahan Stata SE 11

Berdasarkan hasil pada Tabel 4, menunjukkan bahwasanya keputusan model yang terbaik digunakan pada penelitian ini adalah pendekatan model REM. Dari hasil analisis uji Chow memutuskan bahwasanya ketika membandingkan antara model PLS dengan FEM maka keputusan yang diambil ialah FEM merupakan model terbaik. Kemudian, berdasarkan uji Hausman untuk membandingkan antara model REM dan FEM disimpulkan bahwasanya REM merupakan model yang paling baik untuk digunakan. Serta hasil uji LM untuk membandingkan antara model PLS dengan REM juga menunjukkan kondisi keputusan yang sama yakni menyimpulkan bahwasanya pada penelitian ini model yang paling baik digunakan adalah estimasi model REM. Berdasarkan hasil pada Tabel 5 menunjukkan nilai dari $R$-Square sebesar 0.762. Kondisi tersebut menunjukkan bahwasanya perubahan nilai ekspor non migas Indonesia ke negara non tradisional $76.20 \%$ dijelaskan oleh variabel di dalam model seperti variabel GDP riil negara non tradisional potensial sasaran ekspor, jumlah populasi negara non tradisional potensial sasaran ekspor, jarak ekonomi, nilai tukar rill (Rp/LCU), kualitas pelabuhan Indonesia, dan nilai Foreign Direct Investment (FDI) Indonesia. Sedangkan sebesar $23.80 \%$ atau sisanya dijelaskan oleh faktorfaktor di luar model. 
Tabel 5. Faktor-faktor yang Memengaruhi Ekspor non Migas Indonesia ke Negara Non Tradisional

\begin{tabular}{lcc}
\hline \multicolumn{1}{c}{ Variabel } & Koefisien & Probabilitas \\
\hline LN_RGDPj & 0,246 & $0,001^{*}$ \\
LN_Popj & 0,644 & $0,000^{\star}$ \\
LN_EDit & $-0,453$ & 0,121 \\
LN_EXit & 0,255 & $0,004^{\star}$ \\
LN_QPIi & 4,999 & $0,016^{\star}$ \\
LN_SFDI & 1,247 & $0,055^{\star \star}$ \\
A & $-25,362$ & $0,012^{\star}$ \\
\hline R-Squared & & 0.762 \\
Prob (F-statistic) & & 0.000 \\
\hline
\end{tabular}

Sumber: Hasil Olahan Stata SE 11

Keterangan: *) signifikan pada taraf nyata $5 \%$ **) signifikan pada taraf nyata $10 \%$

Pendekatan uji statistik yang dapat dilakukan untuk melihat serta mengetahui variabel independen secara bersamaan memengaruhi variabel terikat (dependen) yaitu menggunakan pendekatan uji Fstatistik. Berdasarkan Tabel 4. menunjukkan bahwa nilai probabilitas dari uji F-statistik sebesar 0.000 atau kurang dari taraf nyata (a) 5\%. Hal ini menunjukkan, di dalam model penelitian setidaknya perubahan nilai ekspor non migas Indonesia terhadap negara-negara non tradisional dipengaruhi oleh salah satu variabel bebas secara nyata ataupun signifikan.

Uji t-statistik digunakan untuk melihat pengaruh masing-masing variabel independen terhadap perubahan nilai ekspor non migas
Indonesia ke negara non tradisional. Berdasarkan hasil estimasi Tabel 5. menunjukkan bahwa variabel-variabel GDP riil dan jumlah populasi negara non tradisional potensial sasaran ekspor, nilai tukar riil rupiah terhadap mata uang negara non tradisional potensial sasaran ekspor, kualitas pelabuhan Indonesia dan variabel alpha $(\alpha)$ signifikan pada taraf nyara 5\% dan positif berpegaruh terhadap perubahan nilai ekspor non migas Indonesia. Kemudian, nilai Foreign Direct Investment (FDI) Indonesia signifikan pada taraf nyata $10 \%$ dan berhubungan positif terhadap perubahan nilai ekspor non migas Indonesia. sedangkan variabel jarak ekonomi antar Indonesia dengan negara importir tidak signifikan dan memiliki hubungan negatif terhadap perubahan nilai ekspor non migas Indonesia.

Uji Pelanggaran asumsi klasik dilakukan untuk memperoleh model yang bersifat BLUE (Best Linear Unbiased Estimator). Akan tetapi, menurut Gujarati (2004) apabila estimasi menggunakan model REM maka uji pelanggaran asumsi klasik tidak perlu dilakukan. Kondisi ini dikarenakan pada model estimasi 
Random Effect Model variabel-variabel yang digunakan di dalam model tersebut diasumsikan sudah bersifat BLUE (Best Linear Unbiased Estimated). Uji normalitas pada model REM diasumsikan menyebar normal. Hal ini dikarenakan menurut Gujarati (2004) model tersebut diasumsikan bersifat central limit theorem serta jumlah data observasi lebih dari 30 $(n>30)$. Pada model pendekatan REM uji pelanggaran asumsi autokorelasi tidak perlu dilakukan. Hal ini disebabkan variabel-variabel dalam model tersebut sudah diasumsikan tidak ada korelasi antar error atau terbebas masalah autokorelasi. Selain itu, Asumsi dasar model REM terbebas dari autokorelasi dikarenakan metode estimasi menggunakan pendekatan Generalized Least Square (GLS), bahkan pada model Random Effect Model (REM) variansi sisaan erornya bersifat konstan (Gujarati, 2004). Selanjutnya uji asumsi klasik multikolinearitas tetap perlu dilakukan untuk melihat dan menunjukkan kondisi hubungan antara variabel bebas (independen) yang digunakan. Hasil uji menunjukkan bahwa tidak terdapat korelasi antar variabel independen di dalam model tersebut atau memenuhi kondisi non multikolinearitas. Hal ini juga dibuktikan dari Tabel 6. yang menunjukkan bahwa nilai VIF kurang dari 10.

\section{Tabel 6. Hasil Uji Multikolinearitas}

\begin{tabular}{lcc}
\hline \multicolumn{1}{c}{ Variabel } & VIF & $1 /$ VIF \\
\hline RGDPj & 1,60 & 0.625 \\
Popj & 1,59 & 0.630 \\
Edit & 1,10 & 0.911 \\
Exit & 1,11 & 0.904 \\
QPIi & 3,43 & 0.291 \\
SFDI & 3,41 & 0.293 \\
\hline Mean VIF & & 2,04 \\
\hline
\end{tabular}

Sumber: Hasil Olahan Stata SE 11

Berdasarkan hasil estimasi pada Tabel 5, diketahui bahwa faktor-faktor yang memengaruhi nilai ekspor non migas Indonesia terhadap negara non tradisional adalah GDP riil jumlah populasi negara non tradisional potensial sasaran ekspor, jarak ekonomi, nilai tukar rill, kualitas pelabuhan Indonesia, dan nilai Foreign Direct Investment (FDI) Indonesia. Hasil estimasi model pada penelitian ini menunjukkan bahwa variabel GDP riil negara non tradisional potensial sasaran ekspor, FDI Indonesia, kualitas pelabuhan Indonesia, populasi negara non tradisional potensial sasaran ekspor, dan nilai tukar riil signifikan dan positif berpengaruh terhadap nilai ekspor non migas Indonesia. sedangkan variabel jarak ekonomi antar negara Indonesia dan negara non tradisional potensial sasaran ekspor 
berpengaruh negatif namun tidak signifikan memengaruhi nilai ekspor non migas Indonesia.

Pengaruh GDP Riil Negara Non Tradisional Potensial Sasaran Ekspor Terhadap Nilai Ekspor Non Migas Indonesia

GDP riil negara non tradisional potensial sasaran ekspor adalah penjumlahan pendapatan nasional dari negara tersebut berdasarkan pendekatan harga konstan pada periode tertentu. Pendekatan variabel ini juga mengindikasikan keadaan dari daya beli masyarakat tersebut. Berdasarkan estimasi pada Tabel 5 menunjukkan bahwasanya slope dari GDP riil negara non tradisional potensial sasaran ekspor signifikan dan positif memengaruhi perubahan nilai ekspor non migas Indonesia dengan koefisien sebesar 0,246. Hal ini didukung dari hasil probabilitas kurang dari a $(0.000<0.05)$. Kondisi ini juga menunjukkan peningkatan GDP riil (daya beli) negara non tradisional potensial sasaran ekspor sebesar berapa 10\% akan meningkatkan nilai ekspor non migas Indonesia sebesar $2,46 \%$ ke negara tersebut dengan asumsi cateris paribus. Hasil penelitian ini sejalan dengan penelitian yang dilakukan oleh Yasri (2016), dimana hasil tersebut menunjukkan bahwa GDP riil negara mitra dagang signifikan dan positif memengaruhi nilai ekspor. Kemudian, hasil penelitian Kahfi (2017) juga menunjukkan hubungan yang sama antara GDP riil negara mitra dengan nilai ekspor yaitu signifikan dan berpengaruh positif terhadap nilai ekspor.

Pengaruh Populasi Negara Non Tradisional Potensial Sasaran Ekspor Terhadap Nilai Ekspor Non Migas Indonesia

Jumlah populasi suatu negara menjadi indikasi yang memengaruhi permintaan impor negara tersebut terhadap negara eksportir. Berdasarkan estimasi pada Tabel 5 menunjukkan bahwasanya slope dari jumlah populasi negara non tradisional potensial sasaran ekspor signifikan dan berpengaruh positif terhadap perubahan nilai ekspor non migas Indonesia dengan koefisien dugaan sebesar 0,644. Kondisi ini mengindikasikan apabila terjadi peningkatan populasi dari negara non tradisional potensial sasaran ekspor sebesar 10\% maka akan berdampak terhadap meningkatnya nilai ekspor non migas Indonesia sebesar $6.44 \%$ dengan asumsi cateris paribus. Penelitian oleh Wardani et al. (2018) 
sejalan dengan hasil penelitian ini yang menunjukkan bahwa jumlah populasi negara mitra dagang signifikan dan positif memengaruhi nilai ekspor.

Pengaruh Nilai Tukar Riil Terhadap Nilai Ekspor Non Migas Indonesia

Berdasarkan hasil estimasi pada

Tabel 5, variabel nilai tukar riil (Rp/LCU) signifikan dan berpengaruh positif pada taraf nyata 10\% terhadap perubahaan nilai ekspor non migas Indonesia dengan nilai koefisien estimasi sebesar 0,255. Hal ini menunjukkan bahwa apabila terjadi peningkatan dari nilai tukar riil (Rp/LCU) sebesar 1\%, maka kondisi ini mengindikasikan nilai tukar rupiah mengalami depresiasi sedangkan nilai tukar negara non tradisional potensial sasaran ekspor mengalami apresiasi sehingga nilai ekspor non migas Indonesia mengalami peningkatan sebesar 2,55\% dengan asumsi cateris paribus. Kondisi tersebut sesuai dengan hasil penelitian Ulfa dan Andriyani (2019) serta Kang dan Dagli (2018) yang menunjukkan hasil bahwa nilai tukar riil berpengaruh positif dan signifikan terhadap ekspor.

Pengaruh Jarak Ekonomi Terhadap Nilai Ekspor Non Migas Indonesia

Jarak ekonomi diindikasikan sebagai biaya transportasi yang harus dikeluarkan untuk melangsungkan perdagangan. Hasil estimasi pada Tabel 5 menunjukkan bahwa variabel jarak ekonomi antar Indonesia dan negara non tradisional potensial sasaran ekspor berkorelasi negatif dan tidak berpengaruh signifikan dengan nilai koefisien dugaan sebesar -0.453 . Hal ini menunjukkan apabila terjadi peningkatan jarak ekonomi antara Indonesia dengan negara tersebut, maka kondisi ini mengindikasikan bahwa biaya transportasi yang harus dikeluarkan semakin besar. Akhirnya tidak akan menurunkan nilai ekspor Indonesia ke negara non tradisional potensial sasaran ekspor dengan asumsi cateris paribus.

Jarak ekonomi tidak signifikan memengaruhi nilai ekspor Indonesia ke negara negara non tradisional potensial sasaran ekspor. Kondisi ini mengindikasikan bahwa jauh atau dekatnya jarak Indonesia dengan negara non tradisional potensial sasaran ekspor tidak memengaruhi besaran nilai ekspor non migas Indonesia. Hasil penelitian tentang pengaruh jarak terhadap ekspor ini sejalan dengan hasil penelitian yang dilakukan oleh Faruk (2015) yang menunjukkan bahwa jarak tidak berpengaruh signifikan terhadap 
perdagangan atau ekspor Bangladesh.

Selain itu menurut Zahro (2013) salah satu penyebab jarak ekonomi tidak signifikan terhadap perdagangan dikarenakan semakin canggihnya fasilitas perdagangan terutama fasilitas transportasi serta penerimaan dari perdagangan yang semakin tinggi.

\section{Pengaruh Kualitas Infrastruktur Pelabuhan Terhadap Nilai Ekspor Non Migas Indonesia}

Kualitas pelabuhan Indonesia (QPI) yang diindikasikan menggunakan pendekatan nilai indek signifikan pada a 5\% serta memiliki pengaruh positif terhadap perubahan ekspor non migas Indonesia dengan nilai koefisien dugaan sebesar 4,999. Kondisi ini menunjukkan bahwasanya apabila terjadi peningkatan kualitas pelabuhan Indonesia sebesar 10\% akan akan meningkatkan nilai ekspor non migas Indonesia ke negara non tradisional potensial sasaran ekspor sebesar $12,47 \%$ dengan asumsi cateris paribus. Hasil penelitian ini sejalan dengan penelitian yang dilakukan oleh Portugal-Perez \& Wilson (2012), Isdiana \& Aminata (2019) dan Grainger A (2007) yang menunjukkan bahwa kualitas pelabuhan Indonesia berpengaruh signifikan dan positif terhadap kinerja ekspor Indonesia.
Pengaruh Foreign Direct Investment Indonesia Terhadap Nilai Ekspor Non Migas Indonesia

Hasil estimasi regresi data panel menunjukkan bahwa variabel Foreign Direct Investment Indonesia memengaruhi ekspor non migas. Hasil estimasi menunjukkan bahwa variabel FDI Indonesia berpengaruh positif dan signifikan pada taraf nyata $10 \%$ dengan nilai koefisien dugaan sebesar 1,247. Hal ini menunjukkan bahwa apabila terjadi peningkatan FDI Indonesia sebesar $10 \%$ maka akan meningkatkan nilai ekspor non migas Indonesia ke negara-negara non tradisional potensial sasaran ekspor sebesar 12.47\% dengan asumsi cateris paribus. Hasil penelitian ini sejalan dengan penelitian yang dilakukan oleh Uysal \& Mohamoud (2018) juga menjelaskan bahwa variabel FDI berpengaruh positif dan signifikan terhadap kinerja ekspor di kawasan Asia Timur.

\section{KESIMPULAN DAN REKOMENDASI KEBIJAKAN}

Hasil penelitian ini menyimpulkan bahwa berdasarkan definisi negara non tradisional yang diadopsi dari penelitian terdahulu adalah negara yang tidak konsisten berada diposisi 15 besar sebagai sasaran ekspor non migas Indonesia selama kurun waktu 30 
hingga 40 tahun. Hasil penelitian menunjukkan bahwa terdapat 111 negara yang terdefinisikan sebagai negara non tradisonal tersebut.

Hasil SMI dan Demand Index menunjukkan ada 17 negara tujuan ekspor non tradisional yang berpotensi sebagai diversifikasi ekspor non migas Indonesia. Mereka adalah Brazil, Cote d'Ivoire (Pantai Gading), Egypt Arab Rep (Mesir), Georgia, Jamaica, Kazakhstan, Kuwait, Myanmar, Nigeria, Norway, Oman, Pakistan, Russian Federation, Trinidad and Tobago, Turkey, United Arab Emirates, dan Uruguay. Hasil pemodelan menggunakan regresi data panel menunjukkan bahwa model yang terbaik/tepat untuk pemodelan nilai ekspor non migas Indonesia adalah Random Effect Model (REM), dimana variabel GDP riil negara tujuan, populasi negara tujuan, dan nilai tukar riil berpengaruh positif dan signifikan secara statistik pada taraf nyata $1 \%$ terhadap nilai ekspor non migas ke negara tujuan non tradisional, sedangkan kualitas pelabuhan dan Foreign Direct Investment berpengaruh positif dan signifikan pada taraf nyata 5\% dan 10\% Namun, jarak ekonomi antara Indonesia dan negara tujuan ekspor tidak signifikan memengaruhi nilai ekspor non migas Indonesia ke negara tujuan ekspor non tradisional.

Skenario yang dapat dilakukan untuk meningkatkan pangsa pasar ekspor non migas Indonesia yaitu negara-negara yang teridentifikasi sebagai pasar ekspor non tradisional layak untuk dijajagi sebagai negara tujuan ekspor Indonesia. Relevan dengan hal tersebut perlu dilakukan intelejen pasar mengenai kebutuhan dan selera dari masing-masing negara tersebut atas produk Indonesia.

Positif dan signifikannya koefisien kualitas pelabuhan Indonesia dalam regresi data panel menunjukkan pentingnya peningkatan kualitas pelabuhan Indonesia untuk meningkatkan ekspor non migas ke negara tujuan non tradisional.

Selain kualitas pelabuhan Indonesia, FDI juga memiliki koefisien yang positif dan signifikan, yang mengindikasikan perlunya melakukan berbagai kebijakan tambahan yang memberikan insentif untuk menarik Foreign Direct Investment ke Indonesia semisal kompleksitas sistem perpajakan ataupun pemberian tax previleges untuk para investor.

\section{UCAPAN TERIMA KASIH}

Penulis mengucapkan terima kasih kepada seluruh Tim Buletin 
Ilmiah Litbang Perdagangan,

Departemen IImu Ekonomi IPB dan

seluruh pihak terkait dalam penulisan

karya ini atas seluruh kesempatan,

kontribusi dan bantuan yang diberikan.

\section{DAFTAR PUSTAKA}

Arifin, Z \& Mawardi, MK. (2017). Pengaruh Produksi, Harga Internasional, dan Nilai Tukar terhadap Volume Ekspor Rumput Laut Indonesia (Studi pada tahun 2009-2014). Jurnal Administrasi Bisnis 3(50):163-171.

Asmarantika \& Oktaviani. (2009). Gejolak Harga Komoditas Pangan Internasional: Dampak Dan Implikasi Kebijakan Bagi Ketahanan Pangan Indonesia. Jurnal Agribisnis dan Ekonomi Pertanian. 3(1): 36-49.

Damayanti, F; Indira, N; Wahyuni, RS; Prayoga, MR; Kevin, G. (2018). ASEAN di tengah rivalitas AS dan Cina: kerja sama ASEAN dengan RCEP dalam mengurangi dampak perang. Indonesian Perspective. 3(2):145-158.

Faruk, MO. (2015). Impact of distance on Bangladeshi export a cross sectional analysis. International Journal of Economics, Commerce and Management 3 (11):217-223.

Firduas, M. (2018). Aplikasi Ekonometrika Untuk Data Panel dan Time Series. Bogor (ID): IPB Press.

Grainger, A. (2007). Custom and Trade Facilitation: From Concept to Implementation. World Custom Jurnal. 2(1):17-29.

Gujarati, D. (2004). Basic Econometrics, Fourth Edition. The McGraw-Hill Companies.

Hadiyanto, YR. (2015). Pengaruh Diversifikasi Ekspor Terhadap Pertumbuhan Nilai Tambah Per Tenaga Kerja Sektor Manufaktur Berbasis Agro dan Non Agro. Jurnal
Buletin Ilmiah Litbang Perdagangan. 2(9):179-200.

Haryotejo, B. (2013). Analisis Diversifikasi Pasar Ekspor Komoditi Udang Indonesia. Jurnal Sosial dan Ekonomi KP 8(1):85-91.

Isdiana, FN \& Aminata, J. (2019). Analisis ekspor Indonesia dengan anggota Apec melalui moda transportasi laut. Diponegoro Journal of Economics. 1(1):131.

ITAPS FEM IPB, [BI] Bank Indonesia. (2019). Laporan Potensi Kerjasama Ekonomi dan Keuangan dengan Pasar Non-Tradisional. (bukan untuk dipublikasi).

Kahfi, AS. (2017). Determinants Of Indonesia's Exports Of Manufactured Products: A Panel Data Analysis. Jurnal Buletin Ilmiah Litbang Perdagangan. 2(10):187-202.

Kang, JW \& Dagli, S. (2018). International trade and exchange rates. Journal of Applied Economics. 21(1):84-105.

Kementerian Perdagangan (Kemendag). (2019). Neraca perdagangan Indonesia tahun 2013-2018. [diunduh 2019 Februari]. Tersedia pada : www.kemendag.go.id.

Lubis, AD. (2010). Analisis yang Memengaruhi Kinerja Ekspor Non Migas Indonesia. Jurnal Buletin Litbang Perdagangan. 1(4):1-13.

Mardiah, S. (2019). Fasilitas Perdagangan dan Ekspor Manufaktur Unggulan Indonesia Ke RCEP (skripsi). Bogor (ID): Institut Pertanian Bogor.

Oktaviani, R; Novianti, T \& Widyastutik. (2008). Integrasi Perdagangan dan Dinamika Ekspor Indonesia ke Timur Tengah (Studi Kasus: Turki, Tunisia, dan Moroko). Junal agro ekonomi 26 (2):167-189.

Oktaviani, R \& Tanti Novianti. (2008). Teori Perdagangan Internasional Dan Aplikasinya Di Indonesia. Bogor (ID): IPB Press. 
Portugal-Perez A, Wilson JS. (2012). Export Performance and Trade Facilitation Reform Hard and Soft Infrasturture. Policy Research Working Paper. 40(7):1295-1307.

Sabaruddin. (2013). Penguatan Diplomasi Ekonomi Indonesia Mendesain Clustering Tujuan Pasar Ekspor Indonesia: Pasar Tradisional vs Pasar Non Tradisional. Jurnal IImiah Hubungan Internasional. 12(2):1-17.

Salvatore, D. (1997). Ekonomi Internasional. Haris Munandar, penerjemah. Jakarta (ID): Erlangga. Ed ke-5.

Stankovsky, J \& Wolfmayr, Y. (2004). Potential Markets for Austrian Exports. Austrian Economic Quarterly 3(2004). :115-126

Sugema, I. (2012). Krisis Keuangan Global 2008-2009 dan Implikasinya pada perekonomian Indonesia. Jurnal IImu Pertanian Indonesia. 17(3):145-152.

Ulfa, R \& Andriyani, D. (2019). Analisis Faktor-faktor yang Mempengaruhi Ekspor Komiditi Non Migas Di Indonesia Tahun 1985-2017. Jurnal Ekonomi Regional Unimal. 2(3):128140.

Uysal, O \& Mohamoud AS. (2018). Determinants of Export Performance
In East Africa. Proceedings of The IIER International Conference, Warsaw, Poland, 16 January 2018.

Wardani, MA; Mulatsih, S \& Rindayati, W. (2018). Competitiveness and Factors Affecting Indonesian Food Industry's Export to Regional Comprehensive Economic Partnership. Etikonomi: Jurnal Ekonomi. 17(2):185 - 198.

World Integrated Trade Solution (WITS). (2019). Ekspor non migas Indonesia ke negara-negara seluruh dunia [internet]. [diunduh 2019 Februari]. Tersedia pada https://www.WITS.co.id.

Wolrd Development Indicator (WDI) dan World Integrated Trade Solution (WITS). (2019). Demand index dan Structural Match Index (diolah) [internet]. [diunduh 2019 Februari]. Tersedia pada https://www.WITS.co.id.

Yasri, B. (2016). Analisis Kinerja Ekspor Non Migas Indonesia Ke Uni Eropa. Jurnal Ilmiah EDUKASI. 4(3):259280.

Zahro, BA. (2013). Analisis Daya Saing dan Faktor-Faktor yang Memengaruhi Ekspor Alas Kaki Indonesia di Kawasan ASEAN dan China [Skripsi]. Bogor (ID): Institut Pertanian Bogor. 